\title{
Comparative Bootstrap DEA Technical Efficiencies and Determinant Factors: Evidence From the Islamic Banks of Bahrain and United Arab Emirates
}

\author{
Abdus Samad $^{1} \&$ Mohammad Ashraful Ferdous Chowdhury ${ }^{2}$ \\ ${ }^{1}$ Department of Finance and Economics, Utah Valley University, UT, USA \\ ${ }^{2}$ Department of Business Administration, Shahjalal University of Science \& Technology, Sylhet, Bangladesh \\ Correspondence: Abdus Samad, Professor of Economics, Department of Finance and Economics, Utah Valley \\ University, 800 W University PKY Orem, UT 84058, USA. Tel: 801-863-8368.
}

Received: September 3, 2019

Accepted: October 28, 2019

Online Published: December 15, 2019

doi:10.5430/rwe.v10n3p291

URL: https://doi.org/10.5430/rwe.v10n3p291

\begin{abstract}
Applying the Bootstrap DEA method the paper obtained the technical efficiencies of the Islamic banks of Bahrain and the United Arab Emirates (UAE) using the panel data of 2011-2016. The paper found the 95 percent confidence interval mean bias-corrected overall technical efficiencies (OTEBC) of the Islamic banks of Bahrain was less than that of UAE. The OTEBC of Bahrain and UAE was 85.4 percent and 99.1 percent respectively suggesting the average inefficiency (14.6 percent) of the Islamic banks of Bahrain was higher than that (0.5 percent) of the UAE bank and the difference was significant. The paper applied the Simar-Wilson regression (both sided truncated) for determining the efficiency factors. The regression results of pooled data found that non-performance loan to total assets (NPLTA), loan to total assets (LOATA), profitability index (ROA), and bank-size (LOGTA) were significant factors. The regression results found that the efficiency of the Islamic banks was positively related to ROA and negatively related to NPLTA, LOANTA, DEPTA, and LOGTA. Results of regression, running the regression separately for Bahrain and UAE, confirmed the findings of pooled results. The country wise regression results of the Bahrain and UAE Islamic banks found that the NPLTA, LOATA, and LOGTA were significant factors and they are negatively related to the efficiency of the Islamic banks. The finding of this paper that LOANTA was negatively related to bank TE supported the finding of Zelenyuk (2015).
\end{abstract}

JEL Classification: C13, C14, G21; G22

Keywords: bootstrap DEA, technical efficiency, determinant, Simar-Wilson Truncated Regression, Islamic banks, Bahrain, UAE

\section{Introduction}

The main hubs of Islamic banking in the Gulf Cooperating Countries (GCC) are Bahrain and United Arab Emirates (UAE). Dubai and Abu Dhabi are financial headquarters of the UAE. The rise of the Islamic banking in these countries was based on the oil-earned revenue and economic growth. The huge increase in oil price in the world market until the global financial crisis in 2008-2009, the OPEC countries, GCC in particular, generated windfall wealth in the world financial markets.

The banking sector of the GCC, Islamic banks, in particular, was in the forefront in providing credit needs of the nation and become an essential factor for economic growth. Although the decline of oil price affected their economic growth, the efficiency of the banking sector, Islamic banks, in particular, remains unexplored.

The inefficiency of banks increases the cost of intermediation and harms the allocation of funds and the profitability of the bank leading bank failure (Samad, 2014). The increased efficiency in banks' deposit mobilization and loan advancement is key to successful entrepreneurs for enhancing the economic growth of a country (Schumpeter, 1911).

Although both Bahrain and UAE are a pioneer in Islamic banking and share a large market share, there is no comparative study of their technical efficiencies. The study of the Islamic bank technical efficiencies across the two counties and the sources of inefficiencies deserves exploration for different interested parties such as public 
authorities supervising and regulating banks, bank management, bank depositors, borrowers, and the policy maker. They are interesting to know their relative efficiency level.

Most importantly, exploring significant factors affecting the technical efficiency of banks, Islamic banks, in particular, is important for bank management for improving the technical efficiency of their banks. Once significant factors were identified, bank management can use them for improving their banks' relative efficiency.

The survey of the banking literature shows no evidence of the study that used bootstrap DEA for estimating the technical efficiencies of the Islamic banks of Bahrain and UAE. Secondly, there was also no study that applied the Simar-Wilson Truncated regression method in determining the technical efficiency of the banks for Bahrain and UAE. So, this study is the first in determining the efficiency and factors that determined the technical efficiency of the Islamic banks of Bahrain and UAE using the Simar-Wilson truncated regression. Thus, this study is an important contribution to the Islamic banking efficiency literature.

This paper is organized as: a brief characteristic feature of the Islamic bank is outlined in section 2. Section 3 provides the survey of the literature. Data, methodology, and models are discussed in section 4. Section 5 provides empirical results. Conclusions are presented in Section 6.

\section{Key Characteristics Feature of Islamic Bank}

The Islamic bank is a different breed of the financial institution. The basic principles of the operation of the Islamic bank are derived from the Quran and Sunnah, the corner-stone of Muslims' way of life. All activities including the banking business are guided by the Quran and the Sariah law.

First, Islamic banks do finance or engage in the activities. Islam prohibits the consumption and production of any harmful activity such as wine, alcohol, and destructive weaponry, etc., firms including Islamic banks do not finance the production and consumption of these businesses.

Second, the most unique feature of Islamic banking is the avoidance of riba (usury) in all financial transactions. This is because, the Quran, the Divine book of Islam strongly prohibits riba in business transactions. The Quran says: ..." whereas Allah permitted trading and forbidden riba" (Quran: 2: 275). However, neither the Quran nor the Prophet of Islamic did define what riba is (Note 1). At present, riba is interpreted as interest. The present scholars of Sariah agreed that the predetermined fixed rate of return is not permitted in the business transactions of the Islamic bank and financing.

Third, the prohibition of riba (usury) in Islam, gave birth the rise in profit and loss sharing (PLS) mode of production. This is the most important characteristic of the Islamic banks that distinguishes the Islamic banks from the interest-based conventional banks. The key features of profit and loss sharing (PLS) is that (i) both parties (bank and borrower) share the outcome of business venture (profit or loss). Unlike conventional bank equity contracts where banks do not bear the risk of financing investments, Islamic banks share the risk of investment. That is, if there are losses, Islamic banks share the losses of investments (ii) Unlike conventional banks' equity contracts where banks enjoy the fixed rate of return from investments, even when there are losses for the project, there is no predetermined rate of returns on investments for Islamic banks. Justice requires that both partners of business must share the risk of the business. Thus, PLS, avoiding of fixed interest, and Sariah based business conduct are key features of the Islamic banks and financing.

\section{Survey of Literature}

The survey of the efficiency literature of Islamic banks is presented in two broad categories. Category A. Efficiency of the Islamic banks. B. Efficiency determinants of the banks/Islamic banks. Important studies in the category of A include the followings:

El-gamal and Inanoglu (2004) estimated the comparative cost efficiency of the Turkish banks for the period 1990-2000 using the data envelopment analysis (DEA) method. They found that the Islamic banks were more efficient due to Islamic banks' asset-based financing.

Sufian and Majid (2006) investigated the comparative efficiency of the foreign and domestic banks of Malaysia during 2001-2005. They found that banks' scale inefficiency dominated pure technical efficiency during the period. They also found that the foreign banks had higher technical efficiency than the domestic banks.

Kumar and Gulati (2008) examined the technical, pure technical and scale efficiencies of the 27 public sector banks of India just for 2004. The empirical evidence of the paper shows public sector banks operated at 88.5 percent level of TE i.e. the inefficiency was 11.5 percent. Only 7 banks were technically efficient. The regression results of the paper found that the off-balance activities positively affected the Indian bank efficiency. 
Samad (2013) investigated the efficiency of Islamic banks using the time-varying Stochastic Frontier function on the Islamic banks of 16 countries. Mean efficiencies between the pre-global financial crisis and the post-global crisis were estimated at 39 and 38 percent respectively and the difference was not statistically significant suggesting that the efficiencies of Islamic banks did not deteriorate during the global financial crisis.

Samad (2013) empirically estimated the technical efficiencies (TE) of Islamic banks of Bangladesh and compared these with conventional banks in deposit mobilizations and loans production for 2010. TE was estimated applying the stochastic frontier production function. The paper found the mean TE of Islamic banks and conventional banks for loans were 59.6 percent and 62.8 percent respectively, and for deposits, the mean efficiency was 0.61 and 0.60 respectively. Parametric tests such as Satterthwaite-Welch t-test, ANOVA F-test, and Walch F-test, found no statistical evidence of significant differences between the TE of Islamic and conventional banks.

Samad (2107) estimated the loan and the deposit efficiencies of the Islamic banks of Malaysia during 2008-2012 applying the Data Envelopment Analysis (DEA) technique. Between the two production efficiencies, the study found that the Islamic banks of Malaysia enjoyed the higher TE in deposit mobilizations than in the loan financings. The average technical efficiency of loan was 83 percent, 88 percent, 87 percent, 97 percent, and 94 percent in 2008, 2009, 2010, 2011, and 2013 respectively whereas the average technical efficiency in deposit mobilizations was 87 percent, 94 percent, 94 percent, 96 percent, 92percent, and 96 percent in 2008, 2009, 2010, 2011, and 2012 respectively. Whereas in loan financing, only four banks in 2008, two banks in 2009, three banks in 2010, two banks in 2011-2012 were efficient both technically and scale-wise. On the other hand, in deposit mobilization, four banks in 2008 and 2009, five banks in 2010 and 2011, three banks in 2012, and five banks in 2013 were efficient technically and scale-wise. Most of the Islamic banks operated below the optimum scale of production.

Applying both parametric method (SFA) and non-parametric frontier methods (DEA) in assessing the cost, profit, allocative, technical, pure technical and scale efficiency of 43 Islamic banks in 21 countries from Middle East, Asia, Africa and Europe over the period 1995-2001, Hassan (2006) found that Islamic banks were more cost inefficient than profit inefficient meaning that Islamic banks were more efficient in profit-making and technical inefficiency dominated the scale efficiency. His study confirmed the findings of Yudistira (2004) who examined the cross-country technical efficiency of 18 Islamic banks of GCC, East Asian, African and Middle Eastern countries during the period 1997-2000 and found that the overall technical inefficiency score of Islamic banks was on average just over $10 \%$.

Sufian and Noor (2009) applied panel DEA method and estimated the technical efficiencies of the MENA Islamic banks and the Asian Islamic banks and then compared their technical efficiency over the period 2001-2006. They found that the efficiency score of the MENA Islamic banks was higher than the technical efficiency of the Asian Islamic banks. Pure technical inefficiency was less prominent than the scale inefficiency i.e. scale inefficiency was the major source of inefficiency.

Using DEA Noor and Ahmad (2012) investigated the efficiency of 78 Islamic banks operating in 25 countries during the period 1992-2009 and found that the technical efficiency of many Islamic banks in the world has increased during and after the global financial crisis period. According to the financial crisis has decreased trust in the conventional banking system in favor of the Islamic banking model. They further found that the pure technical efficiency scores of sampled Islamic banks were higher than their scale efficiency scores which contradicted the findings of Sufian and Noor (2009) and Yudistira (2004).

Using the data of 25 Islamic banks in GCC countries for the period 2003-2009 and applying DEA, Srairi and Kouki (2012) found: (i) the overall technical inefficiency of GCC Islamic banks was the result of pure technical inefficiency (29.3\%) rather than that of the scale inefficiency (17\%). (ii) The overall technical efficiencies of the Islamic banks increased during and after the global financial crisis.

Applying the DEA method, Rahman and Rosman (2013) and Rosman et al. (2014) compared the technical efficiency levels of Middle Eastern Islamic banks with those of their Asian counterparts over periods 2007-2009 and 2007-2010, respectively and found the technical efficiency of Middle Eastern Islamic banks declined, while the technical efficiency of the Asian Islamic banks increased.

Hassine and Limani (2014) examined 22 MENA Islamic banks over the period 2005-2009 found that the pure technical inefficiency was the main source of Islamic banks' technical inefficiency.

Bahrini (2016) examined the technical efficiencies of the 33 MENA Islamic banks during and after the global financial crisis using DEA and bootstrap DEA and found that the technical inefficiencies of the MENA Islamic banks were mainly attributed to pure technical inefficiencies (17.9\%) rather than scale inefficiencies $(9.1 \%)$. 
There are relatively a few studies on the determinant of the efficiency of Islamic banks compared to efficiency studies of the Islamic banks.

In 2009, Sufian (2009) made another study in estimating the various efficiencies and the determinants of these efficiencies of Malaysian. His studies found that the efficiencies were negatively related to bank expenses and economic conditions, while the efficiencies were positively related to loan intensity.

Zelenyuk (2015) using bootstrap DEA and then used truncated regression with double bootstrap (Simar and Wilson, 2000) for determining bank inefficiencies of Ukraine banks with a particular focus on foreign banks. Among various bank-specific factors, equity-asset and log assets were significant factors and they affected the inefficiency of bank negatively. $100 \%$ foreign ownership bank was more efficient than the locally owned banks. Equity capital has a positive impact on bank efficiency.

Nafla and Hammas (2016) compared the technical efficiencies of Islamic banks vis-à-vis conventional banks of eight countries and then determined the determinants of the technical efficiencies using DEA and Tobit model. They found that the asset quality of the Islamic banks had a positive impact during the crisis.

Ftiti, Nafti, and Sreiri (2013) investigated the constant return scale (CRS) and variable return scale (VRS) efficiency of the Islamic bank in GCC countries around the subprime crisis of 2008 using the Data envelopment approach (DEA) and then applied a regression panel analysis to examine the relationship between efficiency scores derived from the DEA to a set of explanatory variables combined (macroeconomic variables and microeconomic variables). Their main finding was that the Islamic bank remained efficient under subprime crisis

Assaf et al (2011) analyzed the technical efficiency of Saudi banks using a two-stage DEA-data envelopment analysis approach. Using the bootstrapped truncated regression model they found, among significant internal factors, bank efficiency was positively related to ROA and liquidity.

Ahmad et al. (2015) estimated the technical efficiency score and the sources of technical efficiency of the conventional banking sector of Pakistan by applying the DEA double bootstrap technique. Applying the bootstrapped truncated maximum likelihood regression model to determine the sources of technical efficiency, they found bank size was irrelevant for technical. Bank liabilities were negatively and significantly affected the efficiency of banks. Privately owned banks significantly perform better than public sector banks in terms of efficiency scores. Privately owned banks significantly perform better than public sector banks in terms of efficiency scores.

To sum: (i) There are more studies on the technical efficiencies of the Islamic banks than there are studies on the determinants of the efficiency of Islamic banks (ii) There is no study on the technical efficiencies as well as on factors determining technical efficiencies. More importantly, there are only limited studies that used the bias-corrected DEA method. So, this study is an important contribution to the Islamic banking efficiency literature.

\section{Data and Methodology}

\subsection{Data}

Panel data on bank inputs (bank fixed capital, employee wages, and bank deposit) and bank outputs (earning assets and gross loans) of Bahrain and UAE during 2014-2016 were obtained from Bank Scope. All data value is expressed in U.S. dollar.

\subsection{Methodology}

First, this paper applied the Bootstrap-DEA Method for Bias Corrected technical and Management Efficiency (te1bc).In spite of the wide application, the DEA method suffers from serious shortcomings, according to Simar and Wilson (1998). (i) DEA method is deterministic. That is, the efficiency score obtained by the DEA does not allow for random error such as machine failure or power out etc. It thus overestimates the efficiency scores of the DMU and leads to biased efficiency (Simar and Wilson, 1998). (ii) The DEA methodology score does not provide a confidence interval. This paper, thus, employs the bootstrap-DEA approach. Bootstrap is a data-based simulation method introduced by Efron (1979). The main idea or objective of bootstrap is to simulate the data generating process (DGP) with repeated sampling. That is, it replicates repeated sampling from the data. As the replicated data set approximates the original data, the sampling distributions of the sample mean and standard deviations generated from the repeated sampling are close to the original ones.

The bootstrap-DEA was first introduced by Simar and Wilson (1998) and it provides estimated efficiency scores of each DMU generated from numerously repeated sampling. The bootstrap-DEA, thus, provides the bias-corrected efficiency scores together with the confidence interval at $\alpha$ level. So, bootstrap-DEA efficiency scores are more accurate and have statistical properties which the DEA method efficiency scores lack. 
Empirically, an estimate of the radial Debreu-Farrell output-based measure of technical efficiency can be calculated by solving a linear programming problem for each data point $\mathrm{k}(\mathrm{k}=1, \ldots, \mathrm{K})$ :

$$
\begin{array}{ll} 
& \quad \hat{F}_{k}^{0}\left(\mathrm{Y}_{\mathrm{k},} \mathrm{X}_{\mathrm{k}}, \mathrm{Y}, \mathrm{X} \mid \mathrm{CRS}\right)=\max _{\theta, Z} \theta \\
\text { s.t. } & \sum_{k=1}^{K} Z_{\mathrm{k}} \mathrm{Y}_{\mathrm{km}} \geq \mathrm{Y}_{\mathrm{km}} \theta_{\mathrm{m}}, \mathrm{m}=1, \ldots, \mathrm{M} \\
& \sum_{k=1}^{K} Z_{\mathrm{k}} \mathrm{X}_{\mathrm{kn}} \leq \mathrm{X}_{\mathrm{kn}}, \mathrm{n}=1, \ldots, \mathrm{N} \\
& \mathrm{Z}_{\mathrm{K}} \geq 0
\end{array}
$$

Where $\mathrm{Y}$ is $\mathrm{K} \times \mathrm{M}$ matrix of available outputs, $\mathrm{X}$ is $\mathrm{K} \times \mathrm{N}$ matrix of available inputs. CRS specifies constant returns to scale. For variables to scale (VRS) a convexity constraint $\sum_{k=1}^{K} Z_{\mathrm{k}}=1$

$\theta$ Is a scalar and represents the efficiency score of each decision making unit (DMU). The range of $\leq \theta \leq 1$, with a value of 1 indicating a point on the frontier and hence a technically efficient DMU; i.e. outputthe of the DMU cannot be increased without increasing inputs. A DMU is inefficient when the value of $\theta<1$; that is, a given output can be produced by reducing inputs of the DMU.

Bias is calculated as follows:

$$
\begin{gathered}
\operatorname{Bias}\left(\hat{\theta}_{k}\right)=\mathrm{E}\left(\hat{\theta}_{k}\right)-\hat{\theta}_{k} . \\
\operatorname{Bias}\left(\hat{\theta}_{k}\right)=B^{-1 \sum_{k=1}^{K}\left(\hat{\theta}_{k}\right) \cdot \hat{\theta}_{k} .}
\end{gathered}
$$

The bias-corrected efficiency score can be expressed as:

$$
\tilde{\theta}_{\mathrm{k}}=\hat{\theta}_{k}-\operatorname{bias}\left(\hat{\theta}_{k}\right)=2 \hat{\theta}_{k}-B^{-1} \sum_{k=1}^{K}\left(\hat{\theta} *_{k}\right) .
$$

The DEA is a linear programming technique, originally developed by Charnes et al. (1978), for constructing the best practice frontier from the observed inputs and outputs of all the sampled Decision-Making Units (DMUs). By comparing DMUs outside the frontier (inefficient DMUs) with those that lie on the frontier (efficient DMUs), this method can provide efficiency measures for each DMU (Coelli et al., 2005). The DEA has two versions. The DEA model proposed by Charnes, Cooper, and Rhodes (1978) is known as the CCR model. It measures the efficiency of the DMU under the assumption of constant returns to scale (CRS). As all DMUs do not operate under the CRS, Banker, Charnes, and Cooper (1984) proposed a DEA model called the BCC model. The BCC model assumes that DMUs operate under a variable return to scale (VRS) (increasing, constant or decreasing returns to scale.

The difference between the CCR and BCC models can be illustrated by the following graph:

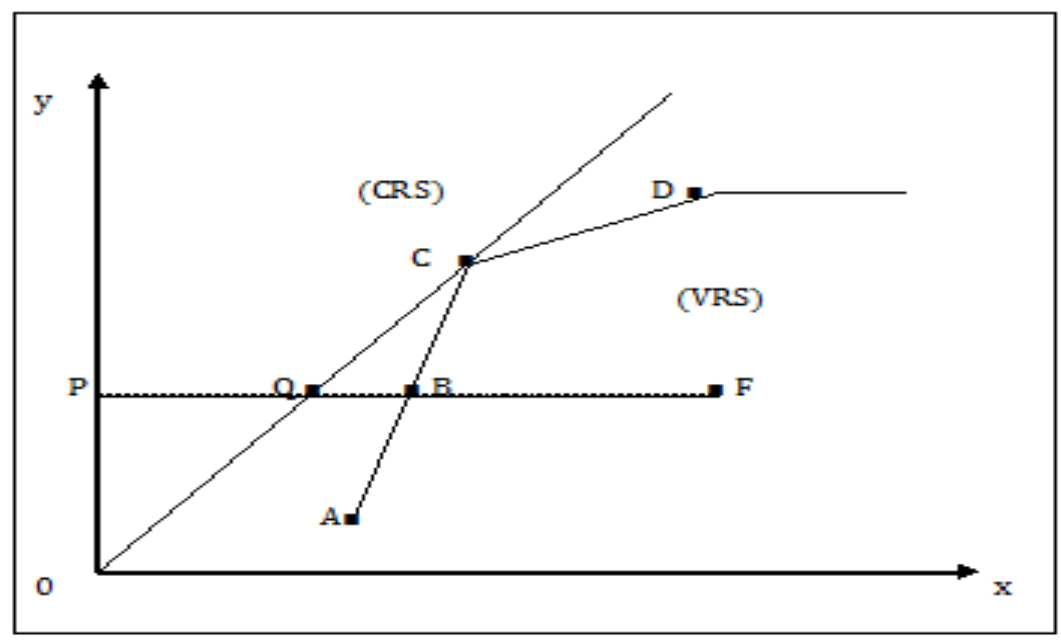

Figure 1. CRS and VRS efficiency frontiers (Coelli et al, 2005)

The line through the points $\mathrm{Q}$ and $\mathrm{C}$ represents the CRS efficiency frontier and the curve (ABCD) represents the VRS efficiency frontier. Each DMU that is on the frontier is technically efficient. For this reason, the particular DMU "F" is technically inefficient. When we refer to the CRS frontier, the distance FQ measures the technical 
inefficiency of the DMU "F". However, when we consider the VRS frontier, the technical inefficiency of the DMU "F" is only the distance FB. The difference between the CRS and the VRS frontiers is the distance QB which is a measure of scale inefficiency.

The overall technical efficiency score (under the CRS frontier): $\mathrm{TE}_{\mathrm{CRS}}=\mathrm{PQ} / \mathrm{PF}$

The pure technical efficiency score (under VRS frontier): $\mathrm{TE}_{\mathrm{VRS}}=\mathrm{PB} / \mathrm{PF}$

The scale efficiency score: $\mathrm{SE}=\mathrm{PQ} / \mathrm{PB}$

From this, we can deduce that $\mathrm{TE}_{\mathrm{CRS}}=\mathrm{TE}_{\mathrm{VRS}} \mathrm{x}$ SE which means that the overall technical efficiency (OTE) of a particular DMU is the product of two efficiencies: pure technical efficiency (PTE) and scale efficiency (SE).

Suppose that there are $\mathrm{n}$ DMUs to be evaluated. Each DMUj, $j=1, \ldots ., n$ uses $m$ different inputs, noted $(i=1, \ldots, m)$, to produce $s$ different outputs, noted $(r=1, \ldots, s)$. The technical efficiency score for a particular DMU, called DMUo, is determined by solving the following linear programming problem. The technical efficiency score $\theta$ for a particular DMU, called DMUo, is determined by solving the following linear programming problem:

$$
\begin{aligned}
& \theta^{*}=\operatorname{Min} \theta \\
& \text { s.t. } \sum_{j=1}^{n} \lambda_{j} x_{i j} \leq \theta x_{i o} \quad i=1, \ldots \ldots, m \text {; } \\
& \sum_{j=1}^{n} \lambda_{j} y_{r j} \geq y_{\text {ro }} \quad r=1, \ldots \ldots, s \text {; } \\
& \lambda_{j} \geq 0 \quad j=1, \ldots \ldots, n \text {; }
\end{aligned}
$$

$\theta<1$ means that the evaluated DMU is technically inefficient. $\theta=1$ Indicates a point on the frontier and hence a technically efficient DMU. In order to estimate the efficiency scores of all the DMUs in the sample, the above problem must be solved $\mathrm{n}$ times, once for each $\mathrm{DMUj}, j=1, n$ (Coelli et al., 2005).

\section{Input-Output Controversy and model selection}

In a production firm such as coal mine, inputs and outputs are easy to find. The output is the amount of coal and the inputs are labor and capital. However, in the multiproduct firms such as a bank which produces a series of services and uses a vector of inputs, deciding inputs and outputs are controversial. Which are the bank's inputs and which are the bank's outputs are a debatable issue for a long time.

Based on production approach (Benston, 1965), a bank is a producer of services for the bank account holders and it produces deposit accounts and loan services with labor and capital. In this sense, the number of deposit account or deposits can be used as output. Depositors' income which is equivalent to interest paid to depositors is an important factor for mobilizing total deposits.

Under the intermediation approach, first used by Sealey and Lindley (1977), the bank is a financial intermediary which collects deposits from the savers and channels funds to borrowers. It treats earning assets as outputs and deposits as inputs. In this sense, loans, investments in securities, and advances are the outputs of a bank and labor, capital, deposits, and expenses related to them are inputs of a bank

Based on Sealey and Lindley (1977), this paper estimates the following model using DEA based on the assumption of Banker, Charnes, and Cooper (Note 2) (1984):

Model 1:

Model 2 (Note 3):

$$
\operatorname{loan}_{\mathrm{i}}=\beta_{0}+\beta_{1} \text { Fixed capital }+\beta_{2} \text { salay }+\beta_{3} \text { Deposit }
$$

Where

$$
\text { Deposit }_{\mathrm{i}}==\beta_{0}+\beta_{1} \text { fixed capital }+\beta_{2} \text { salay }
$$

$\operatorname{loan}_{\mathrm{i}}=$ total loans + Erasset $=$ total earning assets. They are considered as output.

prem $=$ bank fixed capital, salary $=$ Salaries, and Depo $=$ total deposits. They are considered as bank inputs used for producing outputs. 
Thus, the difference between Model 1 and Model 2 is whereas the Model 1 consists of two outputs (loan and earning assets) and three inputs (fixed capital, labor cost, and deposits), Model 2 consists of one output (Deposit) and two inputs (fixed capital and labor costs).

Descriptive statistics of inputs and output variables used in estimating Model 1 and Model 2 for both Bahrain and UAE are provided in Table 1and Table 2.

Second, once technical efficiencies of banks, estimator $\theta_{\mathrm{vrs}}$, were obtained by the bootstrap DEA and then the truncated regression with double bootstrap (Simar and Wilson, 2000) were used for determining the significant factors affecting bank inefficiency/efficiency factor/s. Simar and Wilson claimed that the traditional two-stage DEA with Tobin regression is spurious and inappropriate. Because the technical efficiency score obtained be ordinary DEA method is a relative efficiency score, related to the efficiency of a particular efficient bank/s. That is, they found the efficiency scores were serially correlated. These scores are, thus, interdependent. The use of linearly dependent score as dependents provides a spurious and bias estimate. Second, the efficiency score is not estimated at it is not generated by the repeated sample with $\alpha$ level of confidence attached to it (90\% 0r 95\% confidence). DEA score is simply a calculation. In view of these drawbacks of the DEA, this paper used Simar and Wilson (2007) method which proposed an alternative estimation and has statistical inference procedure based on a double-bootstrap approach.

This estimator $\theta_{\text {vrs }}$ obtained from the bias-corrected bootstrap DEA was then regressed, in the second stage on bank-specific i.e. bank internal factors. That is, a single truncated regression with bootstrap are used for regressing these TE scores of all banks against a set of explanatory factors in the following truncated maximum likelihood regression model.

$$
\theta_{\mathrm{vrs}}=a+\beta \mathrm{Z}_{\mathrm{j}}+\varepsilon
$$

In equation (4), $a$ is the constant term, $\varepsilon_{i}$ is a random error term, identically and independently distributed, and $Z i$ is a vector of bank-specific variables (these are known as bank internal or bank specific factor) for bank $i$ that is expected to be related to the bank's efficiency score.

\section{Description of Z Variables}

The bank-specific factors, Z, used in the bank literature, are numerous. Description of the variables is given under this model are: (1) Bank size. Bank size is measured by total assets (TA) of a bank, usually natural $\log$ of TA. (2) Credit risk/asset quality. Credit risk is measured by: (i) Non-performance loan (past due 90 days) as percentage of total asset (NPLTA) (ii) impaired loan as percentage of gross loans (IMGLOAN), (3) Capital risk/safety is measured by: (i) equity capital as percentage of total asset (EQTA). (4) Liquidity risk is measured by: (i) Loan as a percentage of total assets (LOANTA) and (ii) Deposit as a percentage of the total asset (DEPTA). (4) Profitability index is measured by net profit as a percentage of total assets (ROA). (5) Bank size (LOGTA) represents economies or diseconomies of scale.

The descriptive statistics of bank-specific factors incorporated in $\mathrm{Z}$ is presented in Table 3 .

Using the above bank-specific variables $(Z)$, this paper estimated the following models for determining the efficiency/inefficiency of the Islamic banks applying the Simar and Wilson bootstrap truncated regression:

$$
\begin{gathered}
\text { Loans } \theta_{\mathrm{vrs}}=a+\beta_{1} N P L T A+\beta_{2} E Q T A+\beta_{3} L O A N T A+\beta_{4} R O A+\beta_{5} \operatorname{LogTA} \\
\text { Loans } \theta_{\mathrm{vrs}}=a+\beta_{1} I M G L O A N+\beta_{2} E Q T A+\beta_{3} L O A N T A+\beta_{4} R O A+\beta_{5} \log T A \\
\text { Loans } \theta_{\mathrm{vrs}}=a+\beta_{1} N P L T A+\beta_{2} E Q T A+\beta_{3} D E P T A+\beta_{4} R O A+\beta_{5} \operatorname{LogTA} \\
\text { Deposit } \theta_{\mathrm{vrs}}=a+\beta_{1} N P L T A+\beta_{2} E Q T A+\beta_{3} L O A N T A+\beta_{4} R O A+\beta_{5} \operatorname{LogTA} \\
\text { Deposit } \theta_{\mathrm{vrs}}=a+\beta_{1} I M G L O A N+\beta_{2} E Q T A+\beta_{3} L O A N T A+\beta_{4} R O A+\beta_{5} \operatorname{LogTA} \\
\text { Deposit } \theta_{\mathrm{vrs}}=a+\beta_{1} N P L T A+\beta_{2} E Q T A+\beta_{3} D E P T A+\beta_{4} R O A+\beta_{5} \operatorname{LogTA}
\end{gathered}
$$

Descriptive statistics of the regression variables for (EQ5) - EQ10) are provided in Table 3 and the hypothetical relationship of these variables with bank efficiency is presented in Table 4 and the Regression results of models (EQ 5 - EQ 10) were presented in Table 13 through Table 16. 
Table 1. Descriptive statistics of inputs (Note 4) for Bahrain and UAE during 2014-2016

\begin{tabular}{llrllll}
\hline Year & Bahrain & \multicolumn{3}{l}{ UAE } \\
\hline 2014 & EMEXPSE & \multicolumn{1}{l}{ CAP } & DEPOSIT & EMEXPSE & CAP & DEPOSIT \\
\hline Mean & 50194.83 & 75496.33 & 2738298. & 132908.0 & 223942.8 & 8840421 \\
\hline Median & 26162.50 & 22993.5 & 1144771. & 92582.00 & 58973.00 & 6494474 \\
\hline Maximum & 301308.0 & 379323 & 18649104 & 344039.0 & 654571.0 & 25145124 \\
\hline Minimum & 5096.000 & 11 & 345.0000 & 11348.00 & 3791.000 & 71685.00 \\
\hline Std. Dev. & 82043.92 & 109671 & 5366507. & 127655.3 & 259474.2 & 9167958 \\
\hline 2015 & EMEXPSE & CAP & DEPOSIT & EMEXPSE & CAP & DEPOSIT \\
\hline Mean & 48721.58 & 65784.42 & 2859750. & 154507.0 & 217539.7 & 10338146 \\
\hline Median & 27096.00 & 23592.00 & 1291037. & 130464.0 & 59147.00 & 8753912. \\
\hline Maximum & 298927.0 & 444608.0 & 19355698 & 402897.0 & 702364.0 & 29947292 \\
\hline Minimum & 1851.000 & 15.00000 & 348.0000 & 11382.00 & 3858.000 & 103762.0 \\
\hline Std. Dev. & 81297.19 & 123810.7 & 5568245. & 145993.8 & 261441.5 & 10623786 \\
\hline 2016 & EMEXPSE & CAP & DEPOSIT & EMEXPSE & CAP & DEPOSIT \\
\hline Mean & 52967.00 & 70381.33 & 2678668. & 161910.2 & 225059.0 & 10859222 \\
\hline Median & 29517.50 & 22460.00 & 1388530. & 135326.0 & 59977.00 & 8123665. \\
\hline Maximum & 325501.0 & 417295.0 & 18260566 & 426025.0 & 749993.0 & 33322518 \\
\hline Minimum & 1843.000 & 30.00000 & 348.0000 & 10563.00 & 6068.000 & 127726.0 \\
\hline Std. Dev. & 88665.22 & 120602.7 & 5061271. & 152314.4 & 275505.8 & 11602700 \\
\hline & & & & & & \\
\hline
\end{tabular}

The record of average deposits and employee expenses of the Islamic banks of UAE, in Table 1, showed an upward trend (increasing) during 2014-2016 whereas the average trend of deposit and employee expenses of the Islamic banks showed an upward trend during 2014-2915 and then declined during 2016. The average employee expenses, deposit and fixed capital (capital) of the Bank of UAE were higher than the average employee expenses and deposit of the bank of Bahrain.

Table 2. Descriptive statistics of outputs (Note 5) for Bahrain and UAE during 2014-2016

\begin{tabular}{lllll}
\hline Year & Bahrain & & UAE & Loans \\
\hline 2014 & Earning Asset & Loans & Earning Asset & 8002771. \\
\hline Mean & 3527867. & 2563012. & 9629402. & 5322299. \\
\hline Median & 1728591. & 966617.0 & 6522293. & 21544900 \\
\hline Maximum & 18294374 & 15469663 & 26798952 & 97937.00 \\
\hline Minimum & 119603.0 & 15425.00 & 279982.0 & 7940591. \\
\hline Std. Dev. & 4976655. & 4396588. & 9467552. & Loans \\
\hline 2015 & Earning Asset & Loans & Earning Asset & 9394191. \\
\hline Mean & 3625999. & 2606325. & 11252464 & 6673665. \\
\hline Median & 1757038. & 969960.0 & 8259443 & 27846888 \\
\hline Maximum & 19147544 & 15657512 & 34454849 & 88581.00 \\
\hline Minimum & 118501.0 & 76782.00 & 317908 & 9551700. \\
\hline Std. Dev. & 5221996. & 4447319. & 11459443 & Loans \\
\hline 2016 & Earning Asset & Loans & Earning Asset & 10262914 \\
\hline Mean & 3732867. & 2673932. & 12341040 & 7533228. \\
\hline Median & 2085629. & 1243266. & 9690211. & 32818590 \\
\hline Maximum & 18050805 & 15224021 & 40048437 & 113348.0 \\
\hline Minimum & 118009.0 & 29568.00 & 314697.0 & 10734256 \\
\hline Std. Dev. & 4901528. & 4291946. & 12896513 & \\
\hline & & & \\
\hline
\end{tabular}

The average earning assets and loans of the Islamic banks of both Bahrain and UAE increase over year during 2014-2016. However, the average of both earning assets and loans of the Islamic Banks of UAE were higher than those of the Islamic banks of Bahrain. 
Table 3. Descriptive statistics of bank specific factors for Simar-Wilson Pool Regression

\begin{tabular}{lcccccc}
\hline & NPLTA & IMPGLOAN & LOANTA & DEPTA & ROA & LOGTA \\
\hline Mean & 0.026880 & 0.759228 & 0.518511 & 0.567194 & 0.005511 & 15.10473 \\
\hline Median & 0.011928 & 0.480000 & 0.584693 & 0.699415 & 0.008181 & 15.17344 \\
\hline Maximum & 0.170262 & 0.35000 & 0.914081 & 0.898641 & 0.102527 & 17.67926 \\
\hline Minimum & -0.021429 & 0.070000 & 0.000000 & 0.001383 & -0.087897 & 11.74005 \\
\hline Std. Dev. & 0.033842 & 0.012753 & 0.227003 & 0.264432 & 0.020693 & 1.426383 \\
\hline Skewness & 1.789520 & 0.634632 & -0.995758 & -0.940739 & -0.431124 & -0.416577 \\
\hline Kurtosis & 6.311381 & 13.11934 & 3.112446 & 2.552589 & 11.90525 & 2.730298 \\
\hline Jarque-Bera & 106.9865 & 564.0531 & 17.90452 & 16.67476 & 360.2109 & 3.450975 \\
\hline Probability & 0.000000 & 0.000000 & 0.000129 & 0.000239 & 0.000000 & 0.178086 \\
\hline
\end{tabular}

The probability of Jarque-Bera suggests that all variables were normally distributed. As both NPLTA and IMPGLOAN and LOANTA and DEPTA represent credit risk and liquidity risk, each of them was used separately.

Table 4. Regression variables and hypothetical relationship with technical efficiency/inefficiency (Note 6)

\begin{tabular}{|c|c|c|}
\hline Variables & Technical Efficiency & \\
\hline NPLTA & $(-)$ & \\
\hline IMPGLOAN & $(-)$ & \\
\hline EQTA & & $(-)$ \\
\hline LOANTA & $(-)$ & \\
\hline DEPTA & $(-)$ & \\
\hline $\mathrm{ROA}$ & $(+)$ & \\
\hline LOGTA & $?$ & \\
\hline
\end{tabular}

\section{Empirical Results}

Empirical results of overall bias-corrected technical efficiency (OTEBC) and bias for the Islamic banks of both Bahrain and UAE was presented in Table 5.

The bias-corrected pure technical efficiency (PTE1BC) and the biases of the Islamic bank of Bahrain and UAE are presented in Table 6.

The technical efficiency of the individual bank of Bahrain was presented in Table 7- Table 9. The technical efficiency, OTBC, PTE1BC, and Biases of the individual bank of UAE was presented in Table 10.

Table 5. Over-all Bias Corrected Technical Efficiency (OTEBC) ${ }^{*}$ and Bias ${ }^{*}$ of Bahrain and UAE Bank during 2014-2016

\begin{tabular}{lllll}
\hline Year & Bahrain & & UAE & \\
\hline & Mean OTEBC & Mean Bias & Mean OTEBC & Mean Bias \\
\hline 2014 & $0.809^{*}$ & 0.057 & $0.987^{*}$ & 0.005 \\
\hline 2015 & $0.924^{*}$ & 0.025 & $0.994^{*}$ & 0.003 \\
\hline Mean & $0.829 *$ & 0.048 & $0.993^{*}$ & 0.003 \\
\hline
\end{tabular}

$*=$ The OTEBC efficiency scores significant at 90 percent. 
A comparative examination of overall technical efficiencies (OTEBC) between the Islamic bank of Bahrain and UAE shows the mean technical efficiencies of the bank of UAE and that of Bahrain during 2014-2916 were 99.1 percent and 85.4 percent respectively and the difference is statistically significant. The average technical efficiency of the Islamic bank of UAE was significantly higher than that of the Islamic bank of Bahrain.

Bahrain banks' mean technical efficiency of 85.4 percent suggests that the mean wastage/redundancy of inputs was 14.6 percent compared to 0.09 percent mean inefficiency of the bank of UAE

Table 6. Bias Corrected Pure Technical Efficiency (PTE1BC) ${ }^{*}$ and Bias ${ }^{*}$ of Bahrain and UAE during 2014-2016

\begin{tabular}{lllll}
\hline Year & Bahrain & & UAE & \\
\hline & Mean PTE1BC & Mean Bias & Mean PTE1BC & Mean Bias \\
\hline 2014 & 0.895 & 0.037 & 0.998 & 0.001 \\
\hline 2015 & 0.903 & 0.034 & & \\
\hline 2016 & 0.909 & 0.036 & 0.997 & 0.001 \\
\hline Mean & $\mathbf{0 . 9 0 0}$ & $\mathbf{0 . 0 3 5}$ & $\mathbf{0 . 9 9 5}$ & $\mathbf{0 . 0 0 1}$ \\
\hline
\end{tabular}

$*=$ The PTE1BC efficiency scores significant at 90 percent.

A comparative examination of the bias corrected pure technical efficiencies (TE1BC) between the Islamic bank of Bahrain and UAE shows the mean technical efficiency of the Islamic bank of UAE was 95.5 percent. Whereas the bias corrected mean technical efficiency of Bahrain was 90 percent during 2014-2916. The difference in mean efficiency was statistically significant. The average technical efficiency of the Islamic bank of UAE was significantly higher than that of the Islamic bank of Bahrain.

The mean pure technical efficiency of Bahrain bank $=90$ percent and UAE bank $=99.5$ percent suggests that the managerial efficiency of the Islamic banks of UAE was significantly higher than that of the Islamic banks of Bahrain

The average biases of the estimates of the Islamic banks of UAE were 0.01 percent and were less than that of the Islamic banks of Bahrain.

Table 7. Overall Technical Efficiency (OTE), Overall Bias-corrected Technical Efficiency (OTEBC)* Bias-corrected Pure Technical Efficiency (PTE1BC) ${ }^{*}$, and the Bias ${ }^{*}$ Score of each bank of Bahrain in 2014

\begin{tabular}{|c|c|c|c|c|}
\hline Bank & OTE & OTEBC & PTE1BC & Bias \\
\hline ABC Islamic Bank & 1.000 & 0.872 & 0.932 & 0.128 \\
\hline GFH Financial Group & 0.856 & 0.815 & 0.865 & 0.041 \\
\hline Kuwait Finance House & 0.852 & 0.809 & 0.913 & 0.043 \\
\hline AL Baraka Banking Group & 0.813 & 0.759 & 0.934 & 0.054 \\
\hline Bank Alkhair BSC & 0.845 & 0.792 & 0.868 & 0.053 \\
\hline \multicolumn{5}{|l|}{ First energy bank } \\
\hline Al-Salam Bank-Bahrain B.S.C. & 0.866 & 0.798 & 0.929 & 0.068 \\
\hline Khaleeji Commercial Bank & 0.885 & 0.844 & 0.868 & 0.041 \\
\hline AL Baraka Islamic Bank BSC & 0.854 & 0.810 & 0.842 & 0.044 \\
\hline Bahrain Islamic Bank B.S.C. & 0.853 & 0.805 & 0.861 & 0.049 \\
\hline Ithmaar Holding B.S.C. & 0.840 & 0.789 & 0.942 & 0.051 \\
\hline Average & 0.866 & 0.809 & 0.932 & $\mathbf{0 . 0 5 7}$ \\
\hline
\end{tabular}

$*=$ The OTEBE and PTE1BC efficiency scores significant at 95 percent. 
It was seen in Table 5 that the standard DEA overall technical efficiency (OTE) score overestimates the efficiency of the bank. Based on OTE, the average inefficiency of Bahrain's Islamic banks was $(1-0.866)=13.4$ percent during 2014. When the bias corrected technical efficiency was considered, average inefficiency was 19.1 percent (1-0.809).

An examination of the individual bank's pure technical efficiency, known as managerial efficiency, showed that among the banks of Bahrain, the management efficiency (PTE1BC) of Ithmaar Holding was 94. 2 percent and was the highest in 2014 followed by the efficiency of ABC bank whose efficiency was 93.2 percent. The lowest management efficiency (PTE1BC) bank was Albaraka Islamic banks whose efficiency 84.2 percent. Whereas the overall technical efficiency for ABC Islamic bank (87.3 percent) was the highest in 2014. The second was the Bahrain Islamic bank.

Table 8. Overall Technical Efficiency (OTE), Overall Bias-corrected Technical Efficiency (OTEBC), Bias-corrected Pure Technical Efficiency (PTEBC), and Bias Score of each bank of Bahrain in 2015

\begin{tabular}{|c|c|c|c|c|}
\hline Bank & OTE & OTEBC & PTE1BC & Bias \\
\hline ABC Islamic Bank & 1.000 & 0.950 & 0.936 & 0.050 \\
\hline GFH Financial Group & 0.934 & 0.914 & 0.861 & 0.020 \\
\hline Kuwait Finance House & 0.935 & 0.915 & 0.919 & 0.020 \\
\hline Albaraka Banking Group B.S.C & 0.931 & 0.918 & 0.938 & 0.014 \\
\hline Bank Alkhair BSC & 1.000 & 0.949 & 0.865 & 0.051 \\
\hline \multicolumn{5}{|l|}{ First energy bank } \\
\hline Al-Salam Bank-Bahrain B.S.C. & 0.957 & 0.933 & 0.938 & 0.025 \\
\hline Khaleeji Commercial Bank & 0.930 & 0.911 & 0.895 & 0.019 \\
\hline Albaraka Islamic Bank BSC & 0.926 & 0.908 & 0.826 & 0.018 \\
\hline Bahrain Islamic Bank B.S.C. & 0.938 & 0.922 & 0.902 & 0.015 \\
\hline Ithmaar Holding B.S.C. & 0.937 & 0.920 & 0.955 & 0.016 \\
\hline Average & 0.948 & 0.923 & 0.935 & 0.024 \\
\hline
\end{tabular}

$*=$ The OTEBE and PTE1BC efficiency scores significant at 95 percent.

It was seen in Table 6 that the overall technical efficiency (OTE) score overestimates the efficiency of the bank. Based on OTE, the average inefficiency of Bahrain's Islamic was (1-0.948) $=5.2$ percent in 2015 . When the bias corrected technical efficiency was considered, average inefficiency was 7.7 percent (1-0.923).

An examination of the individual bank's pure technical efficiency, in Table 6, showed that among the banks of Bahrain, the management efficiency (PTE1BC) of Ithmaar Holding was 95. 5percent and was the highest in 2015 followed by the efficiency of Al Baraka Banking Group and ABC Bank whose efficiency was 93.7 percent and 93.5 percent respectively.

Among the Islamic banks, the lowest managerially efficiency (PTE1BC) bank was Albaraka Islamic Banks whose efficiency 82.5 percent. Whereas the OTEBC efficiency of ABC Islamic Bank and Bank alKhair was 94.9 percent and 94.9 respectively and was the highest in 2015. The second was the Bahrain Islamic bank.

Table 9. Overall Bias-corrected Technical Efficiency (OTEBC) ${ }^{*}$, Bias-corrected Pure Technical Efficiency (PTEBC) ${ }^{*}$, and Bias Score of Each bank of Bahrain during 2011-2016

\begin{tabular}{llll}
\hline Bank & OTEBC & PTE1BC & Bias \\
\hline ABC Islamic Bank & 0.888 & 0.938 & 0.112 \\
\hline GFH Financial Group & 0.765 & 0.813 & 0.038 \\
\hline Kuwait Finance House & 0.826 & 0.933 & 0.034 \\
\hline Albaraka Banking Group & 0.785 & 0.941 & 0.032 \\
\hline Bank Alkhair BSC & 0.780 & 0.871 & 0.041 \\
\hline First energy bank & 0.882 & 0.938 & 0.118 \\
\hline
\end{tabular}




\begin{tabular}{llll}
\hline Al-Salam Bank-Bahrain B.S.C. & 0.835 & 0.946 & 0.045 \\
\hline Khaleeji Commercial Bank & 0.864 & 0.881 & 0.030 \\
\hline Albaraka Islamic Bank BSC & 0.829 & 0.861 & 0.027 \\
\hline Bahrain Islamic Bank B.S.C. & 0.856 & 0.921 & 0.025 \\
\hline Ithmaar Holding B.S.C. & 0.815 & 0.960 & 0.030 \\
\hline Average & $\mathbf{0 . 9 2 9}$ & $\mathbf{0 . 9 3 8}$ & $\mathbf{0 . 0 5 0}$
\end{tabular}

*=The OTEBE and PTE1BC efficiency scores significant at 90 percent.

Table 9 showed that showed that among the banks of Bahrain, the management efficiency (PTE1BC) of Ithmaar Holding was 95. 9percent and was the highest in 2016 followed by the efficiency of Al Baraka Banking Group and ABC Bank whose efficiency was 94.0 percent and 93.8 percent respectively.

Table 10. Overall Bias-corrected Mean Technical Efficiency (OTEBC) ${ }^{*}$, Bias-corrected Mean Pure Technical Efficiency (PTE1BC) ${ }^{*}$, and the Bias ${ }^{*}$ Score with upper and upper bound of each bank of UAE during 2011-2016

\begin{tabular}{lccccr}
\hline Bank & OTEBC & \multicolumn{2}{c}{ PTE1BC } & Bias & \multicolumn{2}{c}{$\begin{array}{l}\text { Lower } \\
\text { bound }\end{array}$} \\
\hline ABU Dhabi Islamic Bank & 0.987 & 0.985 & 0.003 & 0.980 & 0.987 \\
\hline Ajman Islamic Bank & 0.990 & 0.990 & 0.007 & 0.980 & 0.996 \\
\hline Dubai Islamic Bank & 0.990 & 0.985 & 0.005 & 0.974 & 0.990 \\
\hline Emirate Islamic Bank & 0.998 & 0.990 & 0.008 & 0.978 & 0.997 \\
\hline Hilal Islamic Bank & 0.992 & 0.990 & 0.002 & 0.988 & 0.992 \\
\hline Al Marwid Islamic Bank & 0.978 & 0.972 & 0.006 & 0.962 & 0.978 \\
\hline Noor Islamic Bank & 0.990 & 0.985 & 0.005 & 0.979 & 0.990 \\
\hline Sharjah Islamic Bank & 0.985 & 0.983 & 0.003 & 0.980 & 0.985 \\
\hline Mean & $\mathbf{0 . 9 9 0}$ & $\mathbf{0 . 9 8 5}$ & $\mathbf{0 . 0 0 5}$ & $\mathbf{0 9 7 8}$ & $\mathbf{0 . 9 8 9}$ \\
\hline
\end{tabular}

$*=$ The OTEBE and PTE1BC efficiency scores significant at 95 percent.

Table 10 showed that the highest efficient banks of UAE were Emirate Islamic Bank and Hilal Islamic Bank. The average OTBE of these banks were 0.998 and 0.992 respectively. The average highest PTE1BC banks were Emirate Islamic Bank and Hilal Islamic Bank, and Ajman Islamic Banks. The average PTE1Bc of these banks was 0.990.

Table 11. Simar-Wilson Pool Regression Results of two outputs and three inputs efficiency determinant of Bahrain-UAE Islamic banks

\begin{tabular}{llll}
\hline Variables & $\mathrm{EQ}(4)$ & $\mathrm{EQ}(5)$ & $\mathrm{EQ}(6)$ \\
\hline Constant & $1.02^{*}$ & 0.98 & $1.01^{*}$ \\
\hline NPLTA & $0.92^{*}$ & & $1.06^{*}$ \\
\hline IMGLOAN & & -0.001 & -0.06 \\
\hline DEPTA & & & -0.23 \\
\hline EQTA & -0.11 & $0.06^{* *}$ & \\
\hline LOANTA & $0.05^{* *}$ & -0.007 & $0.003^{* *}$ \\
\hline ROA & $-0.49^{* *}$ & -0.009 & 43.16 \\
\hline LOGTA & -0.006 & 28.05 & 0.0000 \\
\hline Wald $X^{2}(5)$ & 36.67 & 0.0000 & of \\
\hline Prob $>$ of $X^{2}$ & 0.0000 & . & \\
\hline
\end{tabular}

Inefficiency is dependent variable and two-sided truncated. A negative sign before the coefficient indicates the impact of the regressor on the estimated inefficiency score (obtained on the first-stage of the analysis) and, therefore implies a positive influence of TE. *, **, and $* * *$ indicate the level of significance at $1 \%, 5 \%$, and $10 \%$ respectively. 
When banks were engaged in the production of two outputs (loans and earning assets) in Bahrain-UAE, the regression results found, among factors, NPLTA, LOATA, ROA, and LOGTA were significant factors.

The higher nonperformance loan as a percentage of total assets (NPLTA) negatively affected the technical efficiency (TE) of the Islamic banks of both Bahrain and UAE. That is, banks with high nonperformance loans are less efficient. The result supports the finding of Zelenyuk (2015).

Banks' ROA positively affected the TE of the Islamic banks. The result suggests banks with higher profits are more technically efficient than the banks with a low ROA. The higher the rate of returns of the Islamic banks the higher the technical efficiency of banks. This result supports the finding of Assat et al (2011)

Banks' LOANTA negatively impacted the TE of the Islamic banks. The result suggests that the banks with high liquidity risk are less efficient. This is because when banks have a larger amount of loan per dollar assets, banks face a high liquidity risk. The high liquidity risk of banks, thus, negatively impacted the TE of the Islamic banks.

Bank size (LOGTA) negatively affected the TE of the Islamic bank. The result suggests that large banks are less efficient than small banks. Large banks were less efficient conceivably due to diseconomies of scale. This result of negative relation with TE contradicts the finding of Zelenyuk (2011) in which they found a positive relation between bank size and the TE for the conventional banks of Ukraine.

Table 12. Simar-Wilson Pool Regression Results of single output and two inputs efficiency determinant of Bahrain-UAE Islamic banks

\begin{tabular}{llll}
\hline Variables & $($ EQ 4) & (EQ 5) & (EQ 6) \\
\hline Constant & $0.66^{*}$ & $0.64^{*}$ & $0.58^{*}$ \\
\hline NPLTA & 0.42 & & 0.02 \\
\hline IMGLOAN & & 0.006 & $0.07^{*}$ \\
\hline DEPTA & & $0.07^{* *}$ & $0.11^{* *}$ \\
\hline EQTA & 0.07 & $0.11^{*}$ & -0.12 \\
\hline LOANTA & $0.10^{*}$ & -0.11 & $0.1 .^{*}$ \\
\hline ROA & -.020 & $0.01^{*}$ & 64.75 \\
\hline LOGTA & $0.01^{*}$ & 72.40 & 0.0000
\end{tabular}

Inefficiency is the dependent variable and two-sided truncated. A negative sign before the coefficient indicates the impact of the regressor on the estimated inefficiency score (obtained on the first-stage of the analysis) and, therefore implies a positive influence of TE. *, **, and $* * *$ indicate the level of significance at $1 \%, 5 \%$, and $10 \%$ respectively.

When banks of Bahrain and UAE were engaged in the production of single output (deposit) the regression results found, among factors, LOATA, EQTA and LOGTA were significant factors.

Nonperformance loan as a percentage of total assets (NPLTA) negatively affected the technical efficiency (TE) of the Islamic banks of both Bahrain and UAE. This suggests that banks with a larger ratio of nonperformance loan are less efficient.

Banks' EQTA negatively affected the TE of the Islamic banks. The result suggests that banks with low risk are more technically efficient. When banks have a higher amount of equity capital per dollar asset, the bank's capital risk is significantly reduced. So, a lower risk due to higher EQTA ratio, increases the TE of the Islamic banks.

Banks' LOANTA negatively impacted the TE of the Islamic banks. This is because when banks have a larger amount of loan per dollar assets, banks face liquidity risk. The high liquidity risk negatively impacted the TE of the Islamic banks

Bank size (LOGTA) was negatively related to the TE of the Islamic bank. The result suggests that large banks are less efficient than small banks. Large banks suffer from diseconomies of scale and inefficient loan management. 
Table 13. Simar-Wilson Regression Results of two outputs and three inputs efficiency determinants of Bahrain Islamic banks

\begin{tabular}{llll}
\hline Variables & (EQ 4) & (EQ 5) & (EQ 6) \\
\hline Constant & $0.72^{*}$ & $0.81^{*}$ & $0.95^{*}$ \\
\hline NPLTA & -0.02 & & $1.01^{* *}$ \\
\hline IMGLOAN & & -0.0008 & -0.32 \\
\hline DEPTA & & -0.08 & -0.32 \\
\hline EQTA & -0.04 & $0.12^{*}$ & -0.12 \\
\hline LOANTA & $0.15^{*}$ & -0.53 & 0.006 \\
\hline ROA & -0.42 & 0.007 & 34.10 \\
\hline LOGTA & $0.01^{* * *}$ & 71.04 & 0.0000 \\
\hline Wald $X^{2}(5)$ & 57.11 & 0.0000 & \\
\hline Prob $>$ of $X^{2}$ & 0.0000 & &
\end{tabular}

Inefficiency is the dependent variable and two-sided truncated. A negative sign before the coefficient indicates the impact of the regressor on the estimated inefficiency score (obtained on the first-stage of the analysis) and, therefore implies a positive influence of TE. *, **, and $* * *$ indicate the level of significance at $1 \%, 5 \%$, and $10 \%$ respectively.

When banks were engaged in the production of two outputs (loans and earning assets) in Bahrain, among factors, NPLTA, LOATA, and LOGTA were significant factors. Nonperformance loan as a percentage of total assets (NPLTA) negatively affected the technical efficiency (TE) of the Islamic banks of Bahrain. That is, banks with high nonperformance loans are less efficient in Bahrain.

Banks' LOANTA was a significant and negatively impacted factor affecting the TE of the Islamic banks. The result suggests that the high illiquidity banks are less efficient. This is because when banks have a larger amount of loan per dollar assets, banks face a high liquidity risk. Banks with high illiquidity, thus, faced negative relation to the TE of the Islamic banks.

Bank size (LOGTA) was negatively related to the TE of the Islamic bank. The result suggests large banks are less efficient than small banks. Large banks are inefficient due to diseconomies of scale and inefficient loan management.

Table 14. Simar-Wilson Regression Results of single outputs and two inputs efficiency determinants of Bahrain Islamic banks

\begin{tabular}{llll}
\hline Variables & $($ EQ 4) & (EQ 5) & (EQ 6) \\
\hline Constant & $1.00^{*}$ & $1.07^{*}$ & $1.11^{*}$ \\
\hline NPLTA & -0.86 & & -0.10 \\
\hline IMGLOAN & & 0.003 & $0.05^{*}$ \\
\hline DEPTA & & & -0.12 \\
\hline EQTA & -0.6 & -0.11 & \\
\hline LOANTA & $0.15^{*}$ & $0.13^{*}$ & -0.14 \\
\hline ROA & -0.59 & -0.17 & -0.01 \\
\hline LOGTA & -0.007 & -0.01 & 37.07 \\
\hline Wald $X^{2}(5)$ & 58.47 & 46.68 & 0.0000 \\
\hline Prob $>$ of $X^{2}$ & 0.0000 & 0.000 &
\end{tabular}

Inefficiency is the dependent variable and two-sided truncated. A negative sign before the coefficient indicates the impact of the regressor on the estimated inefficiency score (obtained on the first-stage of the analysis) and, therefore implies a positive influence of TE. *, **, and $* * *$ indicate the level of significance at $1 \%, 5 \%$, and $10 \%$ respectively. 
When banks were engaged in the production of single output (deposit), among factors in Bahrain, LOATA, and DEPTA were significant factors.

Banks' DEPTA were negatively related to the TE of the Islamic banks. The result suggests that banks with high illiquidity risk are technically less efficient. When banks have a higher amount of deposit per dollar asset, banks face significant illiquidity risk in the market. So, the high illiquidity risk due to higher DEPTA ratio, was negatively related to the TE of the Islamic banks.

Banks' LOANTA negatively impacted the TE of the Islamic banks. This is because when banks have a larger amount of loan per dollar assets, banks face liquidity risk. The high liquidity risk negatively impacted the TE of the Islamic banks

Table 15. Simar-Wilson Regression Result of two outputs and three inputs efficiency determinant of UAE Islamic banks

\begin{tabular}{llll}
\hline Variables & $($ EQ 4) & $($ EQ 5) & $($ EQ 6) \\
\hline Constant & $1.02^{*}$ & $1.01^{*}$ & 1.01 \\
\hline NPLTA & -0.02 & & -0.05 \\
\hline IMGLOAN & & -0.0001 & \\
\hline DEPTA & & -0.15 & -0.15 \\
\hline EQTA & 0.16 & 0.01 & -0.52 \\
\hline LOANTA & $0.22^{*}$ & -0.35 & 0.000 \\
\hline ROA & -0.30 & $0.002^{* *}$ & 32.32 \\
\hline LOGTA & -0.000 & 42.78 & 0.000 \\
\hline Wald $X^{2}(5)$ & 42.05 & 0.0000 & of $X^{2}$ \\
\hline Prob $>$ of
\end{tabular}

Inefficiency is the dependent variable and two-sided truncated. A negative sign before the coefficient indicates the impact of the regressor on the estimated inefficiency score (obtained on the first-stage of the analysis) and, therefore implies a positive influence of TE. *,**, and *** indicate the level of significance at $1 \%, 5 \%$, and $10 \%$ respectively.

When banks of UAE were engaged in the production of two output (loan and earning assets), among factors, LOANTA and LOGTA were significant factors for technical efficiency.

Banks' LOANTA negatively impacted the TE of the Islamic banks. This is because when banks have a larger amount of loan per dollar assets, banks face illiquidity risk. The high illiquidity risk negatively impacted the TE of the Islamic banks.

Large bank denoted by (LOGTA) was negatively related to the TE of the Islamic bank. The result suggests large banks are technically less efficient than small banks. Large banks are inefficient due to diseconomies of scale and inefficient loan management.

Table 16. Simar-Wilson Regression Result of single output and two inputs efficiency determinant of UAE Islamic banks

\begin{tabular}{llll}
\hline Variables & (EQ 4) & (EQ 5) & (EQ 6) \\
\hline Constant & $0.81^{*}$ & $0.79^{*}$ & $85^{*}$ \\
\hline NPLTA & 0.14 & & 0.18 \\
\hline IMGLOAN & & 0.008 & 0.05 \\
\hline DEPTA & & 0.06 \\
\hline EQTA & 0.002 & 0.006 & $1.27^{*}$ \\
\hline LOANTA & -0.06 & -0.04 & $0.92^{*}$ \\
\hline ROA & 0.44 & 0.40 & 6.18 \\
\hline LOGTA & $0.009^{*}$ & $0.01^{*}$ & 0.28 \\
\hline Wald $X^{2}(5)$ & 8.33 & 8.26 & 0.14 \\
\hline Prob $>$ of $X^{2}$ & 0.13 & 0.16 & \\
\hline
\end{tabular}

Inefficiency is dependent variable and two-sided truncated A negative sign before the coefficient indicates the impact of the regressor on the estimated inefficiency score (obtained on the first-stage of the analysis) and, therefore implies a positive influence of TE. $* * *$, and $* * *$ indicate the level of significance at $1 \%, 5 \%$, and $10 \%$ respectively. 
When banks were engaged in the production of single output (deposit), among factors in UAE, ROA, and LOGTA were significant factors.

Banks' ROA positively affected the TE of the Islamic banks. The result suggests banks with higher profits are more technically efficient than the banks with a low ROA. The higher the rate of returns of the Islamic banks the higher the technical efficiency of banks.

Bank size (LOGTA) was negatively related to the TE of the Islamic bank. The result suggests large banks are less efficient than small banks. Large banks are inefficient due to diseconomies of scale and inefficient loan management.

\section{Conclusions}

This paper applied the Simar and Wilson (1998) bootstrap DEA approach in estimating the technical efficiencies of the Islamic banks of Bahrain and UAE during 2010-2016. It is applied because of its robustness and bias correction estimates with a $\alpha$ level of confidence intervals.

The paper found (i) the mean overall bias-corrected technical efficiencies of the Islamic bank of UAE and Bahrain were 99.1 percent and 85.4 percent respectively during 2014-2916 i.e. the average inefficiency of the Islamic bank of UAE was lower than the average inefficiency of the banks of Bahrain.

The paper found (ii) the average bias-corrected pure technical efficiencies (TE1BC), known as managerial efficiency, of the Islamic bank of Bahrain and UAE were 95.5 percent 90 percent respectively. Thus, the average technical efficiency of the Islamic bank of UAE was higher than that of the Islamic bank of Bahrain.

After obtaining the bias-corrected technical efficiency scores, the paper applied the Simar and Wilson's two-sided truncated regression in determining the bank-specific factor/s that had a significant impact on the technical efficiency of the Islamic banks of Bahrain and UAE.

Two regressions were run on the efficiency scores of two-outputs (loan and earning assets) and a single output (deposit) separately. The regression results of pooled panel data (Table 8) on two outputs found NPLTA, ROA, LOANTA, and LOGTA were, among factors, significant factors for the technical efficiencies of Islamic banks. The efficiency of the Islamic banks was positively related to ROA and negatively related to NPLTA, LOANTA, DEPTA, and LOGTA.

Banks with more profitability (ROA) ratio were more efficient than bank with less ROA ratio. The result supports the finding of Banks' LOANTA was negatively related to the TE of the Islamic banks. The result suggests that the banks with high liquidity risk are less efficient. This is because when banks have a larger amount of loan per dollar assets, banks face a high illiquidity risk. This result supports the finding of Zelenyuk (2015).

Bank size (LOGTA) negatively affected the TE of the Islamic bank. The result suggests that large banks are less efficient than small banks. Large banks were less efficient conceivably due to diseconomies of scale. This finding of negative relation with TE contradicts the finding of Zelenyuk (2011) in which they found a positive relation between bank size and the TE for the conventional of Ukraine.

The regression results on single output (Table 10) found bank capital risk (EQTA) was a significant factor affecting bank technical efficiency negatively. The result suggests that banks with low risk are more technically efficient. When banks have a higher amount of equity capital per dollar asset, the bank's capital risk is significantly reduced. The result of this paper supports the finding of Assaf et al (2011).

Country-wise regression was run for Bahrain and UAE separately in determining the efficiency factors of the Islamic banks.

The regression results of Islamic banks of Bahrain for two-outputs and single output (Table 10 and Table 11) confirmed the findings of the pooled regression results. The regression (Simar and Wilson) results of the Bahrain Islamic banks found NPLTA, LOATA, and LOGTA were significant factors and they are negatively related to the efficiency of the Islamic banks.

The regression results of the Islamic banks of UAE for two-outputs and single output (Table 12 and Table 13) confirmed the findings of the pooled regression results i.e. LOANTA and LOGTA were significant factors and were negatively related to the technical efficiency of Islamic banks. 


\section{References}

Ahmad, H., Khalil., G. M. dad, \& Nadeem, M. (2015). An analysis of banks performance in Pakistan using two-step double bootstrap dea approach. Pakistan Economic and Social Review, 53(2), 331-350.

Assaf, A. G., Barros, C. P., \& Matousek, R. (2011). Technical efficiency in Saudi banks. Expert Systems with Applications, 38, 5781-5786. https://doi.org/10.1016/j.eswa.2010.10.054

Bahrini, R. (2016). Technical efficiency Analysis of MENA Islamic banks during and after the global financial crisis. Journal of Islamic Banking and Finance, 4(2), 15-24.

Bahrini, R. (2017). Efficiency Analysis of Islamic Banks in the Middle East and North Africa Region, Bootstrap DEA Approach. International Journal of Financial Studies, 5(7), 1-13.

Banker, R. D., Charnes, A., \& Cooper, W. W. (1984). Some models for the estimation of technical and scale inefficiencies in data envelopment analysis. Management Science, 30, 1078-1092.

Benston, G. J. (1965). Branch Banking and Economies of scale. Journal of Finance, 20(2), 312-331.

Charnes, A., Cooper, W. W., \& Rhodes, E. (1978). Measuring the efficiency of decision making units. European Journal of Operational Research, 2, 429-441.

Coelli, T. J., Prasad Rao, D. S., O’Donnell, C. J., \& Battese, G. E. (2005). An introduction to efficiency and productivity analysis (2nd ed.). New York, NY: Springer.

Efron, B. (1979). Bootstrap methods: another look at the Jackknife. Annals of statistics, 7, 1-26.

El-gamal, \& Inanoglu. (2004). Islamic banking in Turkey: Boon or Bane for the financial Sector: Proceedings of the firth Harvard University forum on Islamic Finance. Cambridge: Center for Middle Eastern Studies, Harvard University.

Ftiti, Z., Nafti, O., \& Sreiri, S. (2013). Efficiency of Islamic Banks During Subprime Crisis: Evidence of GCC Countries. The Journal of Applied Business Research, 9(1), 285-303.

Hassan, M. K. (2006). The X-efficiency in Islamic banks. Islamic Economic Studies, 13, 49-78.

Hassine, B. M., \& Limani, R. (2014). The impact of bank characteristics on the efficiency: Evidence from MENA Islamic banks. Journal of Applied Finance and Banking, 4, 237-253

Kumar, S., \& Gulati, R. (2008). An Examination of Technical, Pure Technical, and Scale Efficiencies in Indian Public Sector Banks using Data Development Analysis. Urasian Journal of Business and Economics, 1(2), 33-69.

Nafla, A., \& Hammas, A. (2016). Islamic Finance, Financial crisis, and Determinants of financial stability: Empirical Evidence throughout the two approaches. Journal of Islamic Banking and Finance, 4(1), 47-59.

Noor, M.A.N.M., \& Ahmad, N.H.B. (2012). The determinants of Islamic banks' efficiency changes: Empirical evidence from the world banking sectors. Global Business Review, 13, 179-200.

Rahman, A.R.A., \& Rosman, R. (2013). Efficiency of Islamic banks: A comparative analysis of MENA and Asian countries. Journal of Economic Cooperation \& Development, 34, 63-92.

Rosman, R., Wahab, N. A., \& Zainol, Z. (2014). Efficiency of Islamic banks during the financial crisis: An analysis of Middle Eastern and Asian countries. Pacific-Basin Finance Journal, 28, 76-90.

Samad, A. (2016). Technical Efficiency of Islamic Banks versus Domestic Banks: Evidence from Bangladesh. International Journal of Business and Finance, 10(2), 31-40. Retrieved from http://ssrn.com/abstract=2752712

Samad, A. (2017). Which Efficiency Dominates Production, Deposit vs Loan: Evidence from Islamic Banks, Malaysia During 2008-2012 (Accepted). Journal of Business Studies Quarterly.

Schumpeter, J. A. (1911). The Theory of Economic Development. Harvard University Press, Cambridge, MA.

Sealy Jr., C. W., \& Lindley, J. T. (1977). Inputs, outputs and a theory of production and cost at depository financial institutions. The Journal of Finance, 32, 1251-1266.

Simar, L., \& Wilson, P. W. (1998). Sensitivity analysis of efficiency scores: How to bootstrap in nonparametric frontier models. Management Science, 44, 49-61.

Simar, L., \& Wilson, P. W. (2000). Statistical inference in nonparametric frontier models: The state of the art. Journal of Productivity Analysis, 13, 49-78. 
Srairi, S. A., \& Kouki, I. (2012). Efficiency and stock market performance of Islamic banks in GCC Countries. ISRA International Journal of Islamic Finance, 4, 89-116.

Sufian, F., \& Noor, M.A.N.M. (2009). The determinants of Islamic bank's efficiency changes: Empirical evidence from MENA and Asian banking sectors. International Journal of Islamic and Middle Eastern Finance and Management, 2, 120-138.

Sufian, F., \& Abdul Majid, M. Z. (2006). Bank ownership, Characteristics and Performance: A Comparative analysis of Domestic and Foreign Islamic Banks in Malaysia. Journal of King Abdul Aziz University -Islamic Economics, 21(2), 3-38.

Sufiyan, F. (2009). Determinants of bank efficiency during unstable macroeconomic environment: Empirical evidence from Malaysia. Research in International Business and Finance, 23, 54-77.

Yudistira, D. (2004). Efficiency in Islamic banking: An empirical analysis of eighteen banks. Islamic Economic Studies, 12, 1-19.

Zelenyuk, N., \& Zelenyuk, V. (2015). Driver of efficiency in Banking: Importance of Model Specifications. Working Paper Series, No. WP08/2015, School of Economics, University of Queensland, Australia.

\section{Notes}

Note 1. [Umar b. al-Khattab said, "There are three thing:If God's Messenger had explained them clearly, it would have been dearer to me than the world and what it contains: (These are) kalalah, riba, and khilafah." (Sunan Ibn Majah, Book of Inheritance, Vol. 4, \#2727.

Note 2. Banker, Charnes, and Cooper (1984) estimated the technical efficiency based on the assumption that firms normally operate under the variable returns to scale instead of the constant returns to scale assumed by Charnes, Cooper, and Rhodes (1978)

Note 3. Output of Model 2 is regressed on bank specific factors along with the output of Model 1.

Note 4. All inputs are in million dollars.

Note 5. All outputs are in million dollars.

Note 6. Explanation of signs was discussed in the empirical results 